\title{
GOOGLEDORK, SEBUAH PENDEKATAN LANJUTAN PEMANFAATAN MESIN PENCARI SEBAGAI PENUNJANG LITERASI INFORMASI
}

\author{
Muhammad Zia ul Haq \\ Mahasiswa Magister Teknologi Informasi Universitas Bina Nusantara
}

Pemahaman yang cukup serta penguasaan teknik pencarian yang baik pada mesin pencari merupakan bagian dari keterampilan dalam berteknologi informasi. Penulis mengangkat pembahasan seputar GoogleDork yang merupakan teknik lanjutan (advanced) yang dapat diterapkan pada mesin pencariyang paling terkenal (Google Search) dan paling banyak digunakan saat ini. Pembahasan didahului dengan mendeskripsikan beberapa teknik yang umum digunakan pada mesin pencari tersebut, selanjutnya dikomparasikan dengan teknik GoogleDork. Berdasarkan gambaran dan komparasi yang ada, disimpulkan bahwa teknik GoogleDork memiliki kekurangan dan kelebihan. Adapun kelebihannya terkait efektivitas, efesiensi dan ketepatan hasil. Dimana kelebihankelebihan tersebut merupakan aspek yang sangat menopang terwujudnya Literasi Informasi yang baik.

Kata Kunci: Literasi Informasi, Literasi Digital, Teknologi Informasi, Google Search, GoogleDork

\section{Pendahuluan}

\section{Latar Belakang}

Telah diketahui secara umum bahwa perkembangan pemanfaatan teknologi informasi dewasa ini menunjukkan peningkatan yang signifikan. Hal ini dapat disaksikan dalam kehidupan keseharian masyarakat yang semakin akrab dengan penggunaan perangkat teknologi informasi. Kepemilikan komputer apalagi perangkat seluler yang kini berevolusi menjadi komputer saku, sudah menjadi hal yang sangat lumrah. Demikian pula kemampuan mengoperasionalkan perangkatperangkat tersebut telah menjadi pengetahuan dan kemampuan yang sangat mudah dikuasai. Secara statistik, salahsatu indikator perkembangan ini juga dapat dilihat dari jumlah pengguna internet yang terus bertambah dari tahun ke tahun. Di Indonesia sendiri jumlah pengguna internet pada tahun 2014 mencapai 88,1 juta pengguna ((APJII), 2015, p. 24), dimana pada tahun 2001 pengguna internet di negara ini hanya berkisar 1.9 juta pengguna ((ITU), 2016).

Datayang dirilis APJIIjuga menunjukkan bahwa penggunaan internet untuk kebutuhan pencarian informasi dan data tergolong sangat besar, atau sekitar $68.7 \%$ (p.30). Temuan ini mengindikasikan besarnya peran alat pencarian informasi (search engine) di internet dalam pemerolehan informasi yang dibutuhkan. Popularitas penggunaan mesin pencari sedikit demi sedikit merubah kebiasaan masyarakat dalam mencari dan menemukan informasi yang relevan dengan urusan yang sementara dihadapi. Bahkan, dalam prosiding konferensi kedua ECIL diutarakan bahwa perubahan ini menjadi sesuatu yang sangat fundamental dalam sejarah peradaban manusia pada abad 20, dimana Web dan mesin pencari menjadi pemicu utamanya (Information Literacy, Lifelong Learning and Digital Citizenship, 2014, p. 7).

Mesin pencari, seperti Google dan lainnya merupakan solusi alami bagi pencari informasi yang memerlukan kecepatan dan kehandalan dalam menemukan informasi yang diinginkan (Godwin, 2006, p. 30). Terbentuk melalui siklus hidup teknologi informasi dan aktivitas manusia, penggunaan mesin pencari berevolusi menjadi kebutuhan bagi pencari informasi. Pemanfaatannya, jika dilakukan secara benar, akan mempermudah individu termasuk 
dalam mengidentifikasi, mengevaluasi sekaligus menempatkan dan menggunakan informasi yang diinginkan dan dibutuhkan dari sumber-sumber informasi yang terdapat dalam internet.

Kemudahan yang menunjang produktivitas literasi komputer dan tentunya termasuk Literasi Informasi seperti yang dipaparkan diatas, akan mendatangkan hasil yang maksimal jika sistem kerja yang berjalan dalam mesin pencari tersebut dielaborasi lebih mendalam. Dengan kata lain, hasil yang diberikan dari mesin pencari baik berupa tautan ke sumber informasi ataupun lainnya, akan lebih mutakhir jika penggunaannya dikembangkan dengan metode-metode tertentu.

Salahsatu metode pencarian informasi lanjutan yang dikhususkan pada penggunaan salah satu produk Google (Google Search) adalah teknik Google Dork. Sebuah teknik yang pada awalnya banyak digunakan oleh para peretas untuk menjalankan aksinya dengan memanfaatkan operator lanjutan yang terdapat pada Google Search. Tulisan ini akan melakukan kajian; sejauh mana implementasi pemanfaatan teknik tersebut dan apakah teknik ini juga dapat digunakan untuk menunjang pencarian informasi dan memberikan efektivitias dan efesiensi terhadap Literasi Informasi. Pembahasan pada tulisan ini akan dibatasi pada penggunaan antarmuka Google Search berbasis Web melalui penggunaan salahsatu browser yang berjalan di berbagai sistem operasi.

\section{Landasan Teori}

\section{Literasi Informasi}

a. Definisi

Dari berbagai pengertian seputar Literasi Informasi, yang paling banyak digunakan adalah definisi yang diajukan Asosiasi Perpustakaan Perguruan Tinggi dan Penelitian Amerika Serikat (Association Of College And Research Libraries : ACRL). Dimana, Literasi
Informasi didefinisikan sebagai serangkaian kemampuan yang dibutuhkan setiap individu untuk mengenal kapan informasi dibutuhkan sekaligus kemampuan untuk mengalokasikan, mengevaluasi dan menggunakan informasi yang dikehendaki secara efektif (Presidential Committee on Information Literacy: Final Report, 1989).

b. Tujuan

Tujuan dari Literasi Informasi, sangat tergantung dari kebijakan institusi, pada apa dan siapa serta dalam situasi apa Literasi Informasi tersebut diterapkan (Lloyd, 2010, p. 59). Namun secara umum tunjuannya dapat disimpulkan sebagai berikut:

- Tujuan Strategis, yakni tersedianya suatu metode yang disepakati dan terstandarisasi yang dapat diterapkan dalam usaha mendukung langkah suatu institusi utamanya institusi pendidikan berupa peningkatan kualitas keahlian, kurikulum dan materi serta sistem pembelajaran yang berkelanjutan (Lau, 2006, p. 12)

- Tujuan Operasional, agar setiap individu memiliki keterampilan menemukan akar masalah dan memecahkannya melalui dukungan informasi yang didapatkan.

c. Implementasi

ACRL, 2016 menjelaskan implementasi Literasi Informasi dalam beberapa bidang cakupan, diantaranya:

1. Ilmu pengajaran,

2. Pendidikan tinggi dan

3. Teknologi Informasi

Kefasihan dalam penggunaan teknologi informasi lebih dari sekedar kemampuan menghapal dan menggunakan perangkat keras dan perangkat lunak. Terutama bagi pembelajar, dibutuhkan dukungan kemampuan intelektual untuk memaksimalkan kontribusi kemelekan 
teknologi yang dimilikinya. Literasi informasi merupakan kerangka kerja intelektual untuk memahami, menemukan, mengevaluasi dan menggunakan informasi.

\section{Literasi Informasi dan Literasi Digital}

Literasi Informasi dan Teknologi Informasi merupakan dua terminologi yang memiliki ruang lingkup yang berbeda namun saling silang dan tumpang tindih satu antara lainnya. Literasi Informasi sebagaimana yang telah dijabarkan sebelumnya merupakan bagian terpenting yang membentuk suatu kefasihan dalam berteknologi informasi, sementara teknologi informasi itu sendiri menjadi instrumen utama yang menunjang Literasi Informasi di era digital sekarang ini (Zenelis, 2002). Kefasihan berteknologi informasi ini kemudian oleh UNESCO didefinisikan sebagai keterampilan hidup (life skill) yang mencakup Literasi Informasi dan pemanfaatan teknologi informasi dan kemudian disebut sebagai Literasi Digital (Karpati, 2011, p. 2).

Menurut (Cartelli, 2013, p. 19), pada literasi digital, strategi pencarian (informasi) menjadi hal yang utama. Hal ini terkait dengan keterampilan, imajinasi dan metode yang digunakan dalam memanfaatkan mesin pencari untuk menemukan informasi yang diinginkan. Manfaat tersebut semakin kuat dirasakan karena mesin pencari biasanya menyediakan tautan ke berbagai informasi yang saling memiliki relevansi satu dengan lainnya (Rivoltella, 2008, p. 39). Manfaat ini telah dirasakan sekaligus menjawab kebutuhan $31.75 \%$ pengguna internet (Cartelli, 2013, p.62).

\section{Google Search}

Google Search atau dengan nama yang lebih panjang disebut Google Web Search atau cukup dengan Google (Wikipedia, Google Search, 2016) merupakan mesin pencari informasi melalui antarmuka Web dengan menggunakan fasilitas internet. Dirancang untuk menjelajah dan melakukan indeksasi Web secara efesien sehingga memberikan hasil yang memuaskan (Sergey Brin, 1996). Pada awalnya, di tahun 1996 oleh para pencetusnya diberi nama BackRub yang beroperasi menggunakan server milik Universitas Stanford. Setahun kemudian, pada tanggal 15 September domain Google.com resmi didaftarkan (Our History in Depth, 2016).

Secara internal, Google diimplementasikan dengan bahasa pemrograman $\mathrm{C}$ atau $\mathrm{C}++$ untuk melakukan beberapa fungsi kerja dasar diantaranya; mengenali struktur data, menjelajah Web, indeksasi Web, pencarian data dan informasi dalam halaman Web, melakukan sortir dan memberikan peringkat (Sergey Brin, 1996). Sampai saat ini (Oktober 2016), Google Search telah mengindeks lebih dari 60 triliun halaman Web yang berbeda-beda dan akan terus bertambah seiring dengan perkembangan dan inovasi yang dilakukan pihak Google (Google Inside Search, 2016). Dengan jumlah indeks yang begitu besar dan sistem akses yang sangat dinamis Google Search secara statistik menjadi mesin pencari bahkan Web yang paling banyak digunakan dan dikunjungi (The Top 500 sites on the web, 2016).

\section{GoogleDork}

Dalam Network Dictionary disebutkan bahwa Google Dork atau Google Dorking atau GoogleDork adalah istilah yang dikaitkan dengan pemerolehan informasi sensitif dengan bantuan Google Search (Dong, 2007, p. 218). Istilah dan teknik ini pertama kali dipopulerkan oleh Johnny Long pada tahun 2002 (Wikipedia, Google Hacking, 2016), sebagai istilah yang menggambarkan pemahaman dan pemanfaatan lanjutan dari kode operator yang berlaku di Google Search (Johhny Long, 2016, p. 21). Informasi sensitif sering terkait dengan kerahasiaan pihak tertentu, menyebabkan Google Dork seringkali disebut sebagai Google Hacking dan diasosiasikan dengan kegiatan penetrasi sistem (hacking) (Bort, 2014). Walupun demikian, GoogleDork 
bukan merupakan produk ataupun layanan yang dikeluarkan secara resmi oleh perusahaan Google.

\section{Aspek Kepatutan Pemanfaatan Google Dork}

Adapun dasar implementasi Google Dork seperti yang disinggung diatas, menggunakan operator yang disediakan Google, beberapa diantaranya tercantum dalam halaman bantuan yang disediakan Google (Search Operator, 2016). Selain digunakan oleh pihak tertentu sebagai rangkaian awal dari sebuah aksi penetrasi ke sistem yang memiliki kelemahan, juga dapat digunakan untuk tujuan-tujuan lainnya. Pada hakekatnya fungsi yang tetap "diperbolehkan" pihak Google, dalam batas tertentu sangat mungkin digunakan untuk keperluan positif diantaranya untuk keperluan pendidikan dan pembelajaran.

Sebagian teknik GoogleDork, secara eksplisit telah disediakan melalui antarmuka pengguna https://www.google.com/advanced_search. Tidak sampai disitu, pihak Google juga memberikan bantuan (terbatas) bagaimana memanfaatkan operator yang menjadi dasar implementasi GoogleDork. Bantuan penggunaan operator tersebut dapat diakses pada tautan https://support. google.com/websearch/answer/2466433?hl=id.

\section{Metode}

Karya tulis ini disusun dengan menggunakan metode deskriptif komparatif. Metode ini diimplementasikan dengan mendeskripsikan teknik dan temuan pencarian informasi dengan menggunakan Google Search dengan batasan sesuai yang dijelaskan pada bagian sebelumnya. Deskripsi menggunakan hasil tangkapan layar (capture) yang diperoleh dari pengoperasian seperangkat media berupa komputer jenis Personal Computer, sistem operasi Windows 10 Education Edition dan alat perambah Google Chrome dengan koneksi internet untuk terhubung ke server Google. Penggunaan jenis perangkat, sistem operasi dan jenis browser ini diasumsikan mewakili populasi dan sampel perangkat, sistem operasi dan browser yang digunakan secara umum.

Setiap teknik yang dibahas diperoleh dari beberapa input berupa frasa atau kalimat sebagai instrumen untuk mendapatkan hasil kinerja teknikteknik yang dibahas. Pada bagian akhir deskripsi dan hasil dari setiap teknik, kemudian dikomparasikan berdasarkan beberapa variabel diantaranya efektifitas akses, kemudahan operasional, efesiensi waktu dan ketepatan hasil. Hasil perbandingan dari teknik diatas menjadi jawaban dari masalah yang diajukan pada pendahuluan, kemudian dirangkum menjadi kesimpulan dari karya tulis ini.

\section{Pembahasan Teknik Penggunaan Google Search}

\section{Teknik Dasar}

Merupakan cara pencarian informasi dan data pada Google Search dengan memasukkan kata kunci tanpa simbol atau operator tertentu kedalam antarmuka utama Google Search. Teknik ini dapat dijalankan dengan mengetikkan kata, frasa atau kalimat, atau dengan ucapan melalui mikrofon. Kemudian hasil dari pencarian akan ditampilkan dalam beberapa kolom dan halaman.

Sejalan dengan perkembangan Google Search yang begitu pesat, pihak pengembang membenamkan beberapa fitur yang sangat membantu pengguna pada antarmuka dasar sebagai berikut:

a. Tipe dan Alat Penelusuran

1. Berdasarkan konten, pencarian berdasarkan gambar, peta, video, buku, aplikasi dan lainnya

2. Berdasarkan lokasi dan Bahasa, pencarian berdasarkan lokasi informasi tersebut disimpan atau diproduksi serta menurut bahasa yang digunakan.

3. Berdasarkan hasil (verbatim), menampilkan hasil yang dianggap 
oleh algoritma Google adalah hasil yang kemungkinan besar dicari oleh pengguna bersangkutan.

b. Penelusuran Berorientasi Aplikasi, diantaranya:

1. Kalkulator

2. Konversi Unit dan Nilai

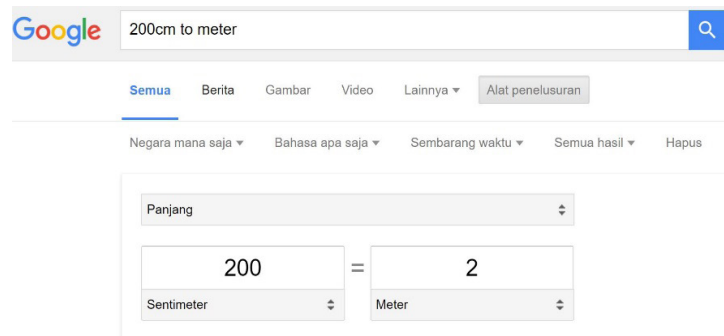

Gambar 1: Fasilitas konversi nilai pada Google Search

3. Popularitas

4. Penerjemah juga dapat diimplementasikan pada teknik lanjutan

5. Lokasi, alamat dan jarak

\section{Teknik lanjutan Google Search}

\section{Antarmuka lanjutan}

Antarmuka lanjutan adalah layanan Google Search yang memiliki halaman tersendiri (khusus) untuk menemukan data dan informasi secara spesifik. Adapun beberapa diantara antarmuka yang dimaksud adalah:

a. Pencarian lanjutan pada tautan https://www. google.com/advanced_search

b. Translasi bahasa pada tautan https://translate. google.com/

Perbedaan dengan pencarian dasar disamping fitur yang lebih lengkap, adalah fasilitas translasi dokumen dengan cara mengunggah berkas dokumen melalui tautan yang disediakan.
Google

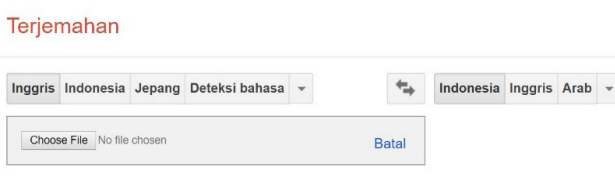

Gambar 2: Fasilitas translasi berkas dokumen pada Google Translate

Cendekia, fasilitas pencarian yang memberikan hasil berupa tautan ke sumber dokumen ilmiah, seperti jurnal dan sumber dokumen artikel lainnya. Fasilitas ini dapat diakses di https://scholar.google. com

Paten, fasilitas pencarian yang memberikan hasil berupa karya ilmiah yang telah memiliki paten. Namun sampai saat tulisan ini dibuat, fasilitas ini masih mencakup paten yang terdapat di negaranegara tertentu dan tidak termasuk Indonesia. Walaupun demikian fasilitas Google Patent dapat diakses dimana saja dengan alamat https://patent. google.com

\section{Tanda Baca dan Operator}

Tanda baca merupakan simbol yang dapat digunakan untuk menemukan informasi spesifik dalam pada form pencarian dasar Google Search (Google, 2016). Sedangkan operator merupakan susunan kata dan tanda baca dengan format tertentu yang dapat digunakan untuk penyaringan penelusuran. Operator penelusuran sebenarnya termasuk penelusuran lanjutan dan telah memiliki antarmuka tersendiri seperti yang telah dijelaskan di atas. Contoh penerapan tanda baca dan operator yang terdapat pada halaman bantuan Google:

\begin{tabular}{|c|l|}
\hline Simbol & Fungsi \\
\hline+ & $\begin{array}{l}\text { Menelusuri laman Google+ atau golongan darah } \\
\text { Contoh: +Chrome atau AB+ }\end{array}$ \\
\hline & $\begin{array}{l}\text { Menemukan tag sosial } \\
\text { Contoh: @aGoogler }\end{array}$ \\
\hline
\end{tabular}




\begin{tabular}{|c|c|}
\hline$\$$ & $\begin{array}{l}\text { Menemukan harga } \\
\text { Contoh: nikon } \$\end{array}$ \\
\hline \# & $\begin{array}{l}\text { Menelusuri hashtag populer untuk topik yang } \\
\text { sedang ngetren } \\
\text { Contoh: \#pusingpalaberbi }\end{array}$ \\
\hline- & $\begin{array}{l}\text { Membantu untuk kata dengan beberapa makna, } \\
\text { seperti Jaguar merek mobil dan jaguar binatang. } \\
\text { Contoh: jaguar speed -car (kecepatan jaguar } \\
\text {-mobil) atau pandas -site:wikipedia.org (panda } \\
\text {-site:wikipedia.org) }\end{array}$ \\
\hline " & $\begin{array}{l}\text { Memberikan hasil frasa yang sama persis. } \\
\text { Contoh:"mau dibawa ke mana hubungan kita" }\end{array}$ \\
\hline * & $\begin{array}{l}\text { Pengganti istilah yang tidak ditemukan. } \\
\text { Contoh:"lain * ladang * lain belalang" }\end{array}$ \\
\hline .* & $\begin{array}{l}\text { Memisahkan angka dengan dua titik tanpa spasi } \\
\text { untuk melihat hasil yang berisi angka dalam kisaran } \\
\text { yang diberikan. } \\
\text { Contoh: kamera } \$ 50 . . \$ 100\end{array}$ \\
\hline
\end{tabular}

Tabel 1: Tanda baca yang dapat digunakan dalam penelusuran, sumber (Google, 2016)

\begin{tabular}{|c|c|}
\hline Operator & Fungsi \\
\hline site: & $\begin{array}{l}\text { Mendapatkan hasil dari situs atau domain } \\
\text { tertentu. } \\
\text { Contoh: olympics site:nbc.com dan olympics site: } \\
\text { gov }\end{array}$ \\
\hline related: & $\begin{array}{l}\text { Menemukan situs yang mirip dengan alamat Web } \\
\text { yang telah Anda ketahui. } \\
\text { Contoh: related:time.com }\end{array}$ \\
\hline OR & $\begin{array}{c}\text { Menemukan laman yang mungkin menggunakan } \\
\text { salah satu dari beberapa kata. } \\
\text { Contoh: marathon OR race }\end{array}$ \\
\hline info: & $\begin{array}{c}\text { Mendapatkan informasi tentang alamat Web, } \\
\text { termasuk versi laman yang tersimpan dalam } \\
\text { cache, laman serupa, dan laman yang tertaut ke } \\
\text { situs. } \\
\text { Contoh: info:Google.com }\end{array}$ \\
\hline cache: & $\begin{array}{l}\text { Melihat tampilan laman saat terakhir kali Google } \\
\text { mengunjungi situs tersebut. } \\
\text { Cont: cache:washington.edu }\end{array}$ \\
\hline
\end{tabular}

Tabel 2: Operator yang terdapat pada halaman bantuan Google Search

\section{Teknik GoogleDork}

Sebagaimana yang telah dijelaskan

sebelumnya bahwa teknik GoogleDork merupakan teknik yang dilakukan dengan menggunakan tanda baca dan operator yang berlaku di Google Search untuk memperoleh informasi spesifik. Adapun beberapa teknik tersebut dapat dijelaskan sebagai berikut:

\section{Operator tambahan}

Selain operator yang telah terdapat pada Web resmi Google, berikut ini daftar beberapa operator lain yang dapat digunakan dalam Google Dork berikut contohnya:

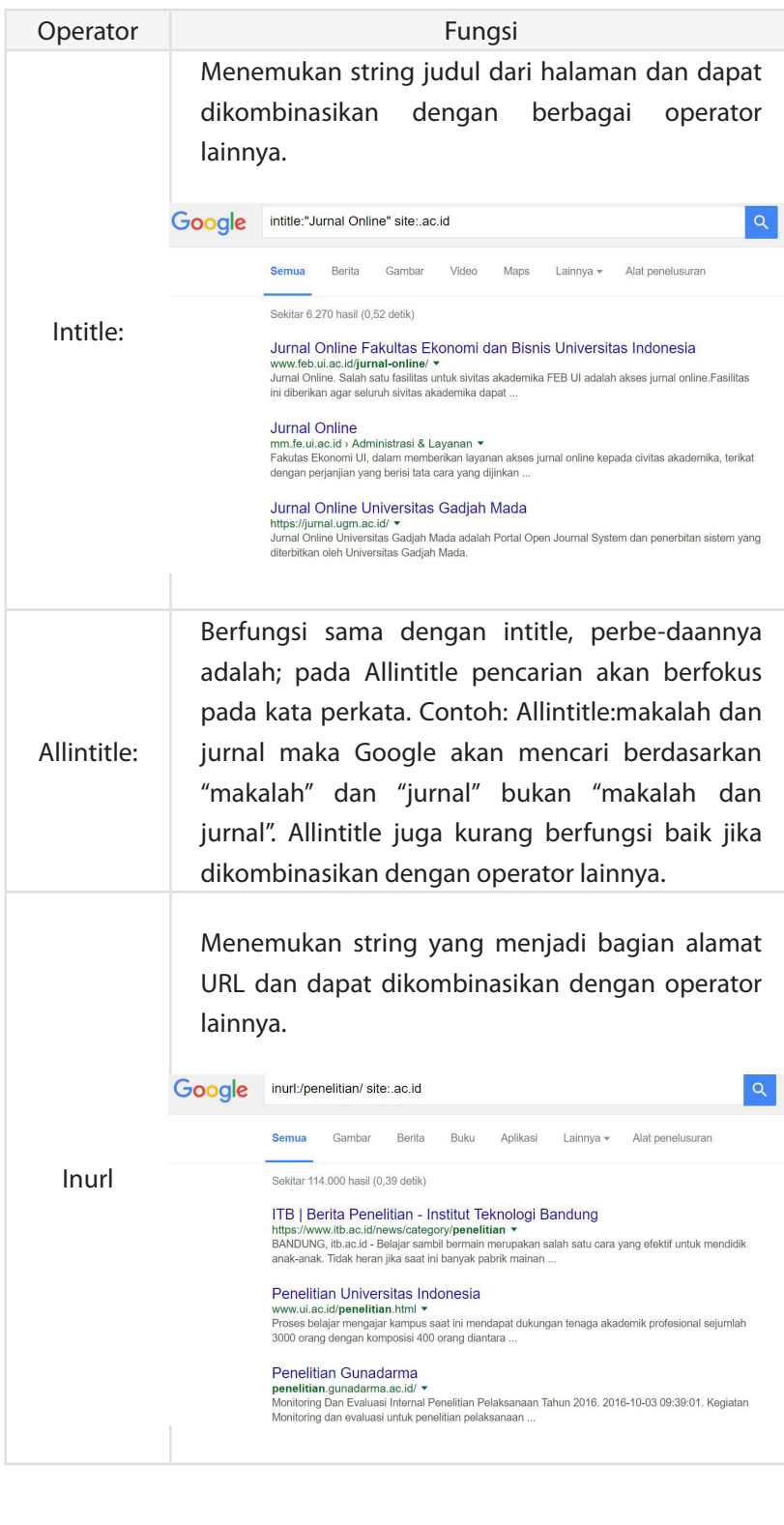




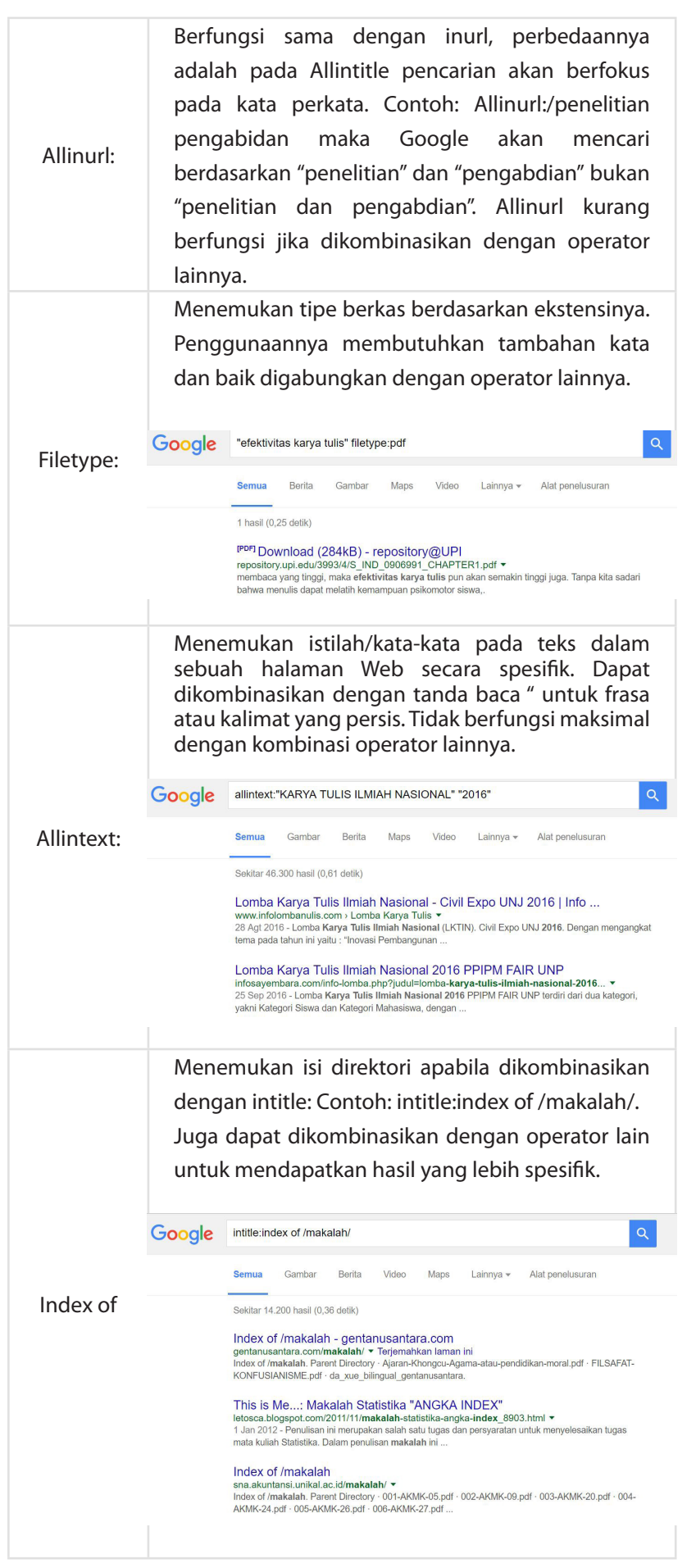

Tabel 3: Fungsi operator yang digunakan dalam GoogleDork

Pemakaian operator dapat dikembangkan sesuai dengan imajinasi serta kebutuhan pengguna. Pengembangannya dapat dilakukan dengan memberikan kata/frasa/kalimat (string) yang spesifik dan dikombinasikan dengan operator lainnya agar penelusuran menampilkan hasil yang paling sesuai dengan yang dikehendaki.

\section{Komparasi Hasil Pencarian}

Berikut ini tabel yang memberikan gambaran komparatif hasil penelusuran yang dilakukan dengan penelusuran dasar, penelusuran antarmuka lanjutan dan penelusuran dengan menggunakan operator dengan teknik GoogleDork:

\begin{tabular}{|c|c|c|c|}
\hline Variabel & $\begin{array}{c}\text { Penelusuran } \\
\text { Dasar }\end{array}$ & $\begin{array}{c}\text { Penelusuran } \\
\text { Antarmuka } \\
\text { Lanjutan }\end{array}$ & $\begin{array}{c}\text { Penelusuran } \\
\text { dengan } \\
\text { operator dan } \\
\text { GoogleDork }\end{array}$ \\
\hline $\begin{array}{c}\text { Efektivitas } \\
\text { akses }\end{array}$ & Baik & Kurang & Sangat baik \\
\hline Efesiensi waktu & Sangat Baik & Baik & Sangat baik \\
\hline Ketepatan hasil & Kurang & Baik & Sangat baik \\
\hline Fitur pencarian & Sangat baik & Baik & Kurang \\
\hline $\begin{array}{c}\text { Penguasaan } \\
\text { teknik }\end{array}$ & Baik & Baik & Kurang \\
\hline
\end{tabular}

Tabel 4: Komparasi penggunaan teknik penelusuran

Efektivitas akses ke daftar sumberinformasi dari hasil penelusuran menggunakan teknik GoogleDork dinilai sangat baik. Hal ini berdasarkan fakta bahwa hasil yang diberikan dengan menggunakan teknik memanfaatkan operator/ GoogleDork memberikan pilihan-pilihan tautan yang tidak begitu banyak dibandingkan dengan menggunakan 2 (dua) teknik lainnya. Meski dalam jumlah yang lebih sedikit, namun hasilnya merupakan hasil-hasil pilihan yang sangat dekat dengan apa yang sedang ditelusuri oleh pengguna. Sehingga pengguna tidak perlu melakukan akses halaman demi halaman pada hasil penelusuran untuk mendapatkan hasil yang sesuai. Efektivitas ini juga sangat terkait dengan efesiensi waktu dan ketepatan hasil. Dengan jumlah hasil penelusuran yang tidak begitu banyak namun berkualitas, pengguna dapat mengefisiensikan waktunya untuk aktivitas lain.

Tabel diatas juga menunjukkan bahwa kelemahan dari penggunaan operator dan GoogleDork terletak pada fitur pencarian yang tidak selengkap yang dimiliki oleh penelusuran dasar. 
Artinya teknik GoogleDork tidak dapat digunakan untuk menampilkan hasil seperti fungsi aplikasi pada penelusuran dasar atau fungsi-fungsi yang terdapat pada antarmuka lanjutan (translate dan lainnya). Penggunaan GoogleDork juga dianggap oleh penulis lebih sulit dikuasai dibandingkan teknik pencarian lainnya. Pengguna diharuskan menghapal dan mengerti fungsi-fungsi dari setiap operator yang ada, disamping itu diperlukan wawasan dan pengetahuan awal untuk mendapatkan kata kunci yang benar-benar sesuai agar mendapatkan hasil yang benar-benar diinginkan. Sementara penelusuran dasar dan antarmuka lanjutan dapat dengan mudah dioperasikan, hal ini dikarenakan pihak Google telah menyediakan antarmuka yang memang mudah dipahami dan dimanfaatkan oleh pengguna.

\section{Penutup}

\section{Kesimpulan}

Berdasarkan deskripsi, contoh dan komparasi yang diuraikan pada pembahasan dapat disimpulkan beberapa kesimpulan sebagai berikut:

1. Pada era digital sekarang ini dan kedepannya, Literasi Informasi tidak dapat dilepaskan dari penggunaan teknologi informasi.

2. Literasi informasi yang dikolaburasikan dengan penguasaan teknologi informasi dapat menghasilkan apa yang disebut sebagai kefasihan dalam teknologi informasi atau biasa disebut dengan Literasi Digital.

3. Salahsatu wujud Literasi Informasi di era digital adalah kemampuan memanfaatkan mesin pencari berbasis Web dengan sangat baik untuk mendapatkan hasil penelusuran yang spesifik dan berkualitas.

4. Pemanfaatan mesin pencari, khususnya Google Search sebagai mesin pencari yang paling banyak mengindeksasi informasi dapat dioptimalkan dengan memahami beberapa cara kerja sistem dan teknik penggunaannya.

5. Salahsatu teknik penggunaan Google Search yang dapat digunakan untuk menunjang Literasi Informasi adalah GoogleDork, disamping teknik-teknik lainnya yang secara resmi disediakan dan didokumentasikan oleh pihak Google

6. GoogleDork merupakan aktivitas legal jika digunakan untuk keperluan yang baik, disamping belum ada aturan suatu negara yang melarangnya, pihak Google sampai saat ini belum mengeliminasi operator yang dapat digunakan dalam implementasinya.

7. Dari hasil deskripsi dan komparasi disimpulkan bahwa, disamping kekurangan dari beberapa aspek, GoogleDorkjuga memiliki kelebihan dari teknik penelusuran lainnya, yakni efektivitas akses, efesiensi waktu dan ketepatan hasil. Yang mana kelebihan-kelebihan tersebut sangat menunjang Literasi Informasi.

\section{Saran}

Dari kesimpulan diatas, penulis merekomendasikan beberapa saran terutama bagi seluruh pihak yang terlibat dalam proses belajar mengajar di sekolah dan universitas juga untuk masyarakat secara umum, sebagai berikut:

1. Mengasah diri untuk lebih tajam dalam memahami dan mengimplementasikan Literasi Informasi serta keterampilan lainnya yang terkait dengan aktivitas pengajaran dan pembelajaran untuk mewujudkan lingkungan pembelajar seumur hidup (lifelong learning).

2. Senantiasa mengembangkan keterampilan dalam memanfaatkan teknologi informasi utamanya untuk tujuan edukatif.

3. Memahami cara kerja sistem dan teknik pemanfaatan mesin pencari sebagai alat yang sangat membantu untuk menemukan sumber-sumber informasi yang dibutuhkan.

4. Menindaklanjuti hasil dari karya tulis 
dan penelitian yang bermanfaat untuk meningkatkan kualitas hidup masyarakat.

5. Terkait dengan pembahasan dalam tulisan ini, Penulis mengharapkan terbitnya suatu karya ilmiah lanjutan yang dapat mencantumkan daftar kata kunci GoogleDork secara intuitif dan lengkap yang berguna untuk tujuan pendidikan dan penelitian. Sebagaimana terdapatnya Web khusus yang memuat daftar lengkap kata kunci GoogleDork untuk tujuan penetrasi kelemahan sistem komputer (Hacking)

\section{Daftar Pustaka}

(APJII), I. A. 2015. Profil Pengguna Internet Indonesia 2014. Diakses dari Asosiasi Penyelenggara Jasa Internet Indonesia: https://apjii. or.id/downfile/file/PROFILPENGGUNAIN TERNETINDONESIA2014.pdf

Bort, J. 2014. Term Of The Day: 'Google Dorking'. Diakses dari Business Insider: http://www.businessinsider.co.id/ term-of-the-day-Googledorking-20148/?r=US\&IR=T\#1D65tJW3MXrmYofM.97

Brin, Sergey and L. P. 1996. The Anatomy of a Large-Scale Hypertextual Web Search Engine. Stanford: Stanford University.

Cartelli, A. 2013. Fostering 21st Century Digital Literacy and Technical Competency. Hershey: IGI Global.

Dong, J. 2007. Network Dictionary. Saratoga: Javvin Technologies, Inc.

Godwin, P. 2006. Keeping up with the Google generation: the challenge for Information Literacy teachers. In P. Godwin, Information Literacy: Recognising the Need (p. 58). Oxford: Chandos Publishing.

Google. 2016. Tanda Baca \& Simbol. Diakses dari Bantuan Penelusuran Web: https://support. google.com/websearch/answer/2466433?hl=id
Google Inside Search. 2016. Diakses dari https://www. google.com/insidesearch/howsearchworks/ thestory/

Information Literacy Competency Standards for Higher Education. 2016. diakses dari Association of College \& Research Libraries: Information Literacy Competency Standards for Higher Education

(ITU), I. T. 2016. Indonesia Internet Users. Diakses dari Internet Live Stats: http://www.internetlivestats. com/internet-users/indonesia/

Lau, J. 2006. Guidelines on Informatiion Literacy for Life Long Learning. The International Federation of Library Associations and Institutions (IFLA).

Long, Johhny and B. G. 2016. Google Hacking for Penetration Testers, Third Editiion. Amsterdam: Elsevier Inc.

Search Operator. 2016. Diakses dari Search Help: https://support.google.com/websearch/ answer/2466433?hl=en\&visit_id $=1-6361301655$ 42327910-1684145910\& $r d=1$

Zenelis, A.S. 2002.Technology Across the Curriculum: Information Literacy and IT Fluency. In A. S. Zenelis, Guidelines on Informatiion Literacy for Life Long LearningTechnology Everywhere A Campus Agenda for Educating and Managing Workers in the Digital Age. San Fransisco: Jossey-Bass. 